\title{
Effect of white clover rich grass pasture allowance on $\alpha$-tocopherol and selenium content in cow milk
}

\author{
T. Bolstad ${ }^{1}$, T.H. Garmo ${ }^{1,3}$, A. Haug ${ }^{1}$, H. Volden ${ }^{1}$, A. Bernhoft ${ }^{2}$ \\ and O.M. Harstad ${ }^{1}$ \\ ${ }^{I}$ Department of Animal and Aquacultural Sciences, Norwegian University of Life Sciences \\ P.O. Box 5003, 1432 As, Norway \\ ${ }^{2}$ National Veterinary Institute \\ P.O. Box 8156 Dep., 0033 Oslo, Norway
}

\begin{abstract}
The objective of this study was to examine the effect of high (HPA, $24 \mathrm{~kg} \mathrm{DM} / \mathrm{cow}$ per day) and low (LPA, $12 \mathrm{~kg} \mathrm{DM} / \mathrm{cow}$ per day) pasture allowance of a white clover rich grass pasture on $\alpha$-tocopherol and selenium in milk. Four multiparous cows of Norwegian Red were used in a Latin square design. Two experiments were conducted: Experiment 1 in mid pasture season with $7 \mathrm{~kg}$ concentrate per cow/day, and experiment 2 in late pasture season with $3 \mathrm{~kg}$ concentrate per cow/day. In mid pasture season, milk $\alpha$-tocopherol concentration was higher on the HPA treatment; $0.63 \mathrm{mg} / \mathrm{kg}$, compared to the LPA treatment; $0.28 \mathrm{mg} / \mathrm{kg}(\mathrm{P}=0.09)$. However, this effect was not seen in late pasture season. There was no statistically significant effect of pasture allowance on milk selenium (mean $10.6 \mu \mathrm{g} / \mathrm{kg}$ ) in these experiments.
\end{abstract}

KEY WORDS: $\alpha$-tocopherol, selenium, cow, milk, allowance, pasture

\section{INTRODUCTION}

Milk lipids can undergo auto-oxidation. With increased content of polyunsaturated fatty acids in milk there is a need to balance this with increased content of anti-oxidants. There are several anti-oxidants in milk. In the milk fat globule membrane the fat-soluble vitamin $\mathrm{E}$, carotenoids and ubiquinol function as radical scavangers. The major vitamin $\mathrm{E}$ in milk is $\alpha$-tocopherol, present both in the cream fraction and in the milk fat globule membrane. At normal rations, the concentration of $\alpha$-tocopherol per gram fatty acid is highest in the milk fat globule membrane (Lindmark-Måneson and Åkesson, 2000).

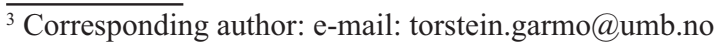


Although not an anti-oxidant in itself, selenium is an essential component of the anti-oxidant enzyme glutathione peroxidase. Glutathione peroxidase function as an anti-oxidant by removing $\mathrm{H}_{2} \mathrm{O}_{2}$ and other peroxides. Approximately $12 \%$ of milk selenium is bound to milk glutathione peroxidase (Hojo, 1982).

In another paper (not published yet) of the same two experiments, we looked the effect of pasture allowance on milk fatty acid composition. We found increased content of polyunsaturated fatty acids (PUFA) in milk on high pasture allowance (HPA) compared to the low pasture allowance (LPA) in both experiments. In Experiment 1, the PUFA content were 4.6 and $4.3 \%$ of total milk fatty acids for the HPA and LPA treatment, respectively $(\mathrm{P}=0.08)$ and in Experiment 2 similar results were 5.0 and $4.6 \%(\mathrm{P}=0.00)$.

The objective of this study was to follow up these results and see if the antioxidant $\alpha$-tocopherol and selenium in milk followed the same pattern as PUFA.

\section{MATERIAL AND METHODS}

\section{Cows, diet and experimental design}

Four multiparous lactating cows of Norwegian Red were used in these experiments. None of the cows were pregnant at the onset of the experiment and produced $31.0 \pm 8.0$ and $23.6 \pm 6.3 \mathrm{~kg}$ milk at the start and end of the experiments, respectively.

The experimental design was a $2 \times 2$ Latin square, with 2 cows in each square. Each animal/treatment period lasted for 2 weeks with the first 9 days as an adaptation period followed by a 5 days data and sample collection period. One milk sample per cow and period was analysed for $\alpha$-tocopherol and selenium. The experiment was conducted twice; Experiment 1 in week 25-28 and Experiment 2 in week 32-35. The same four cows were used in both experiments. Cows were given 7 and $3 \mathrm{~kg}$ per day of a barley and oat based commercial concentrate mixture (Formel Favør 30, Felleskjøpet) in Experiments 1 and 2, respectively. The concentrate mixture contained supplemental vitamin $\mathrm{E}$ ( $\alpha$-tocopherol acetate) and selenium (selenite) in amounts of 50 and $0.25 \mathrm{mg}$ per $\mathrm{kg}$, respectively.

\section{Treatments}

The treatments were full-time grazing on pasture at two different levels of pasture allowance: high pasture allowance (HPA), a daily pasture allowance target of $24 \mathrm{~kg}$ $\mathrm{DM} /$ cow per day and low pasture allowance (LPA), a daily pasture allowance target of $12 \mathrm{~kg} \mathrm{DM} /$ cow per day, measured from $5 \mathrm{~cm}$ above ground level. 
The swards were predominantly white clover (Trifolium repens), with coverage percentage of 60 and 55\% in Experiments 1 and 2. Smooth meadow-grass (Poa pratensis), meadow fescue (Festuca pratensis) and timothy (Phleum pratense) were the main grass species.

\section{Chemical analyses}

Selenium in milk, concentrate and pasture was determined by hydride generation atom absorption spectrometry (Varian VGA-76) according to Govasmark et al. (2005) with the only exception that for milk, $10 \mathrm{~g}$ was used as the amount of starting material. The analysis was carried out at the National Veterinary Institute of Norway.

Milk $\alpha$-tocopherol was analysed by reversed phase HPLC at Vitas AS, Oslo. One $\mathrm{mL}$ of milk was diluted with $3 \mathrm{~mL}$ 2-propanol containing the internal standard tocol and BHT as an antioxidant. After thorough mixing (15 min) and centrifugation (10 min, $4000 \mathrm{~g}$ at $10^{\circ} \mathrm{C}$ ), an aliquot of $20 \mu \mathrm{L}$ was injected from the supernatant into the HPLC system. HPLC was performed with a HP 1100 liquid chromatograph (Agilent Technologies, Palo Alto, CA, USA) with a HP1100 fluorescence detector, em: $295 \mathrm{~nm}$ ex: $330 \mathrm{~nm}$. Tocopherol isomers were separated on a $2.1 \times 250 \mathrm{~mm}$ reversed phase column. A two-point calibration curve was made from analysis of a $3 \%$ albumin solution enriched with known concentration of tocopherols. $\alpha$-tocopherol of pasture and concentrate was analysed at AnalyCen AS, Kambo.

\section{Statistical analyses}

Statistical analyses were done separately for the two experiments.

Model: $\mathrm{Y}_{\mathrm{ijk}}=\mu+\mathrm{T}_{\mathrm{i}}+\mathrm{C}_{\mathrm{j}}+\mathrm{P}_{\mathrm{k}}+\mathrm{e}_{\mathrm{ijk}}$

$\mathrm{T}_{\mathrm{i}}=$ fixed effect of pasture allowance $(\mathrm{i}=\mathrm{HPA}, \mathrm{LPA})$

$\mathrm{C}_{\mathrm{j}}=$ fixed effect of cow $(\mathrm{j}=1,2,3,4)$

$\mathrm{P}_{\mathrm{k}}=$ fixed effect of period $(\mathrm{k}=1,2)$

$\mathrm{e}_{\mathrm{ijk}}=$ error

Statistical analyses were done with SPSS General Linear Model (SPSS, 2003).

\section{RESULTS AND DISCUSSION}

Content of $\alpha$-tocopherol and selenium of pasture and concentrate used in the two experiments is presented in Table 1. Same concentrate mixture was used in both experiments. Model means (EM Means) and standard error of means (SEM) of milk $\alpha$-tocopherol and selenium at two levels of pasture allowance are presented in Table 2. 
Table 1. $\alpha$-tocopherol and selenium content of pasture and concentrate in the two experiments

\begin{tabular}{lccccccc}
\hline & \multicolumn{2}{c}{ Experiment 1} & & \multicolumn{2}{c}{ Experiment 2} & & Exp. 1 and 2 \\
\cline { 2 - 3 } & pasture & SEM & & pasture & SEM & & concentrate \\
\hline$\alpha$-tocopherol, $\mathrm{mg} / \mathrm{kg} \mathrm{DM}$ & 15.8 & 0.55 & & 14.1 & 5.4 & & 91.5 \\
Selenium, $\mathrm{mg} / \mathrm{kg} \mathrm{DM}$ & 0.076 & 0.044 & & 0.011 & 0.000 & & 0.37 \\
\hline
\end{tabular}

Table 2. $\alpha$-tocopherol and selenium in milk at low (LPA) and high (HPA) pasture allowance

\begin{tabular}{|c|c|c|c|c|c|c|c|c|}
\hline & \multicolumn{4}{|c|}{ Experiment $1(\mathrm{n}=8)$} & \multicolumn{4}{|c|}{ Experiment $2(\mathrm{n}=8)$} \\
\hline & LPA & HPA & SEM & P-value & LPA & HPA & SEM & P-value \\
\hline & 0.28 & 0.63 & 0.076 & 0.09 & 0.42 & 0.30 & 0.047 & 0.23 \\
\hline Selenium, $\mu \mathrm{g} / \mathrm{kg}$ & 11.8 & 11.3 & 0.25 & 0.29 & 10.3 & 9.3 & 0.35 & 0.18 \\
\hline
\end{tabular}

$\alpha$-tocopherol

Content of $\alpha$-tocopherol of the pasture used in the two experiments averaged $14.9 \mathrm{mg} / \mathrm{kg}$ DM. Two samples from each experiment were analysed, and there seems to be no trend with season. Lynch et al. (2001) reported $\alpha$-tocopherol content of white clover to be $7.5 \mathrm{mg} / \mathrm{kg} \mathrm{DM}$, and Tramontano et al. (1993) reported $\alpha$-tocopherol content to be 4-7 times less in white clover compared to different grass species. Randby et al. (2002) studied $\alpha$ - and $\gamma$-tocopherol content in grass cut at different stages and found a linear reduction from $35 \mathrm{mg} / \mathrm{kg} \mathrm{DM}$ in early May to $15 \mathrm{mg} / \mathrm{kg}$ DM in late June. Content of $\alpha$-tocopherol of the concentrate mixture used in the two experiments was $91.5 \mathrm{mg} / \mathrm{kg}$ DM.

In Experiment 1, $\alpha$-tocopherol level in milk was twice as high on the HPA treatment compared to the LPA treatment, 0.63 and $0.28 \mathrm{mg} / \mathrm{kg}$, respectively (P-value: 0.09). However, this tendency was not seen in Experiment 2. Average $\alpha$-tocopherol concentration in milk in these two experiments was $0.41 \mathrm{mg} / \mathrm{kg}$ (range: $0.20-0.78 \mathrm{mg} / \mathrm{kg}$ ). $\alpha$-tocopherol levels between 0.2 and $0.7 \mathrm{mg} / \mathrm{L}$ in bovine milk have been reported by different authors (Jensen, 1995). However, Lindmark-Månsson found $\alpha$-tocopherol level of $1.0 \mathrm{mg} / \mathrm{kg}$ in Swedish bulk milk (Lindmark-Måneson and Åkesson, 2000). Although $\alpha$-tocopherol level seems to be within the reported range in the current experiment, it should be noted that the milk was stored for 1.5 years at $-20^{\circ} \mathrm{C}$ before analyses. Vidal-Valverde et al. (1993) has reported a 10 to $21 \%$ decrease of $\alpha$-tocopherol level in ultrahigh-temperature processed (UHT) milk after four to eight months of storage at $-20^{\circ} \mathrm{C}$.

\section{Selenium}

Content of selenium of the pasture used in the two experiments averaged $0.043 \mathrm{mg} / \mathrm{kg} \mathrm{DM}$ and is similar to content in a grass and clover mixture $(0.044 \pm 0.002 \mathrm{mg} / \mathrm{kg} \mathrm{DM})$ found by Gissel-Nielsen (1975). However there was a 
wide range in content from 0.011 to $0.12 \mathrm{mg} / \mathrm{kg} \mathrm{DM}$ in the four pasture samples analysed. Selenium content in concentrate mixture was $0.37 \mathrm{mg} / \mathrm{kg} \mathrm{DM}, 8.6$ times higher than in pasture grass.

There was no significant effect of pasture allowance on milk selenium in these experiments. There was a strong positive correlation $(\mathrm{r}=0.73)$ between milk selenium and milk linoleic acid (C18:2) and a strong negative correlation $(\mathrm{r}=-0.76)$ between milk selenium and milk $\alpha$-linolenic acid (C18:3, n-3). Linoleicand $\alpha$-linolenic acid are probably indicators of high and low concentrate to pasture ratio, respectively.

In the current experiments content of milk selenium averaged $10.6 \mu \mathrm{g} / \mathrm{kg}$ (range: 8 to $14 \mu \mathrm{g} / \mathrm{kg}$ ). Alaejos and Romero (1995) compared 15 studies conducted in The Netherlands, Germany, Norway and Finland, and found mean selenium content in bovine milk to be $9.9 \mu \mathrm{g} / \mathrm{L}$ (range: 3.9 to $23.2 \mu \mathrm{g} / \mathrm{L}$ ). In milk from the southeast area of Norway, Frøslie et al. (1985) reported selenium content of 11 and $16 \mu \mathrm{g} / \mathrm{kg}$ in summer and winter milk, respectively.

\section{CONCLUSIONS}

In mid pasture season, high compared to low pasture allowance doubled the concentration of $\alpha$-tocopherol in milk from 0.28 to $0.63 \mathrm{mg} / \mathrm{kg}$ ( $\mathrm{P}=0.09$ ). This effect was not seen in late pasture season. There was no significant effect of pasture allowance on milk selenium in these experiments. Mean milk selenium content for both experiments was $10.6 \mu \mathrm{g} / \mathrm{kg}$. $\alpha$-tocopherol and selenium levels in milk are within reported range.

\section{REFERENCES}

Alaejos M.S., Romero C.D., 1995. Selenium concentration in milks. Food Chem. 52, 1-18

Frøslie A., Moksnes K., Øvernes G., 1985. The effect of selenium supplementation of animal feeds in Norway. Acta Agr. Scand. 35, 139-144

Gissel-Nielsen G., 1975. Selenium concentration in Danish forages crops. Acta Agr. Scand. 25, 216-220

Govasmark E., Steen A., Strøm T., Hansen S., Singh B.R., Bernhoft A., 2005. Status of selenium and vitamin E on Norwegian organic sheep and dairy cattle farms. Acta Agr. Scand., Sect. A, Anim. Sci. 55, 40-46

Hojo Y., 1982. Selenium concentration and gluthatione peroxidase activity in cows milk. Biol. Tr. Elem. Res. 4, 233-239

Jensen R.G., 1995. Fat-soluble vitamins in milk. In: Handbook of Milk Composition. San Diego, Academic Press, pp. 718-725

Lindmark-Månsson H., Åkesson B., 2000. Antioxidative factors in milk. Brit. J. Nutr. 84, Suppl. 1, 103-110 
Lynch A., Kerry J.P., Buckley D.J., Morrissey P.A., Lopez-Bote C., 2001. Use of high pressure liquid chromatography (HPLC) for the determination of cda-tocopherol levels in forage (silage/ grass) samples collected from different regions in Ireland. Food Chem. 72, 521-524

Randby Å.T., Haug A., Kvam A.S., Bernhoft A., Lindstad P., Volden H., Bævre L., 2002. Chemical composition and fatty acid concentration of fresh grass, hay and grass silage harvested at different stage of maturity (in Norwegian). Animal Science Research Meeting 2002, pp. 549-552

SPSS, 2003. SPSS Base 12.0 User's Guide. SPSS Inc., Chicago

Tramontano W.A., Ganci D., Pennino M., Dierenfeld E.S., 1993. Distribution of $\alpha$-tocopherol in early foliage samples in several forage crops. Phytochemistry 34, 389-390

Vidal-Valverde C., Ruiz R., Medrano A., 1993. Effect of frozen and other storage conditions on alfatocopherol content of cow milk. J. Dairy Sci. 76, 1520-1525 